\title{
EFFECT OF CAREER PLATEAU ON HEAD NURSES' CAREER AND JOB SATISFACTION, AND TURNOVER INTENTION \\ ${ }^{1}$ Asmaa Elwan Mohammed Hassan, ${ }^{2}$ Abeer Mohammed Zakaria, ${ }^{3}$ Awatef Hassan Kassem
}

1, 2, 3 Department of Nursing Administration, Faculty of Nursing, Mansoura University, Egypt

\begin{abstract}
Background: Today, at one time or another, everybody's career reaches a point where further hierarchical development is limited. Head nurses have to face the fact that they have to remain longer than expected in the same place and become plateaued with various negative work outcomes such as career dissatisfaction, job dissatisfaction, and turnover. So, the study aim to determine the effect of career plateau on head nurses career and job satisfaction and turnover intentions at Main Mansura University Hospital .Subjects and Methods: A descriptive design was used in this study and the convenient sample was used that conducted on 98 head nurses working at Main Mansoura University Hospital by using two tools as: Career Plateau Questionnaire to assess career plateau .Career Satisfaction, Job Satisfaction and Turnover Intention Questionnaire to assess Career Satisfaction, Job Satisfaction and Turnover Intention . Results: There was no significant correlation between career plateau and career, job satisfaction and turnover intention among head nurses $(n=98)$. The mean score of total career plateau was highest $(41.18 \pm 3.65)$, and the mean

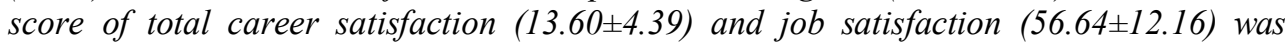

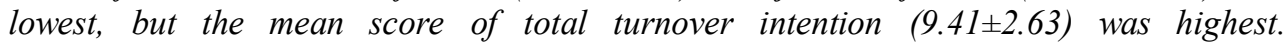
Recommendation: Create a real plan to improve the careers of the head nurses to reduce the career plateau. Identify and manage the factors that create positive attitudes towards increasing head nurse effectiveness, collaborative management and recruitment. Keywords: Career Plateau, Career Satisfaction, Job Satisfaction, Turnover Intention.

Keywords: Career Plateau, Career Satisfaction, Job Satisfaction, Turnover Intention.

\section{Introduction}

One of the main difficulties facing the future was how to prepare and handle jobs. This must be done in a way that addresses the needs and challenges faced by their organizations and their employees. We were witnessing a lot of competition in today's world of complex and changed access to the latest power and dominance technology and resources, especially human resources and creative people ${ }^{(1)}$. The hospital head nurses play a significant role and perform a different work such as nursing unit management, organization and strategic planning within a hospital or

other health care institution. Head nurses that stay with less diversity in the same job and at the same level. A number of qualified head nurses with higher work experience in hospital fields have less hope for hospital mobility and stagnation leading to the career plateau ${ }^{(2)}$.

A career is mainly series and variety of paid or unpaid work roles that individuals perform during their lives, but it is also a framework that allows individuals to consider valuable job opportunities and how their work roles contribute to their broader life roles. Nowadays, careers becoming a ' patchwork ' of jobs and continuously
\end{abstract}


upward opportunities are limited, which is not designed or anticipated by the person leading to plateau phenomena

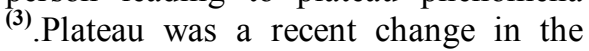
work institution and the workforce was already well established that assuming the current position was low interest with a reduction in the average tenure of the employees. It is a reduction of the hierarchical promotion and neglects the aspect of work-content that has the potential for a career plateau ${ }^{(4)}$.

Career plateau (CP) was not a new occurrence but that it is becoming increasingly widespread. Is characterized as a time in a career where there is considerably low probability of further upward development and endorsements.

In career success, it is a persistent and impermanent discontinuation that triggers frustration and psychological distress. It is a condition where an individual is restricted in the course of work and improved horizontally and vertically movement ${ }^{(5)}$. CP have been impacted by a weak economy, a decrease in size, inadequate recruiting and hiring strategies directed at the same hospital, or an increased management role that leads to no chance for advanced development and unable to meet their career goals and plans, So that career plateau is viewed as one of the factors of non- optimal job results such as career dissatisfaction, job dissatisfaction, and increased job absence (6). Career satisfaction (CS) was a key factor determining the career plateau. It was described as positive psychological and job-related effects or accomplishments obtained by a head nurse as a result of working experience. This is the degree to which a head nurse thinks that his or her career development is compatible with his or her own objectives, beliefs and preferences (7). CS was generally influenced by the satisfaction of the head nurses with their career achievements and requires supports of goal-specific environmental and facilities, which provide social and material support for the personal goals of the workers, contributing to significant work outcomes such as job satisfaction and decreased turnover intention. ${ }^{(8)}$. Job satisfaction (JS) was central to head nurses ' working lives and to the effective use of organizational staff. It was characterized by individuals as an overall affective orientation towards the work roles they currently occupy. It is the efficiency and progress of a worker on the job ${ }^{(9)}$.JS may be influenced by the work environment evaluation of staff, organizational support levels, and the employment condition If a head nurse was satisfied at work, he or she was likely to be more flexible, efficient, achieved towards organizational goals, they tend to perform their jobs better and this would increase their job security in the hospital for years to come. While dissatisfied workers would experience intentions of leaving from working places (10). Turnover intention (TI it was the employee's desire to abandon their company. It has been found that the desire to withdraw is a predictor of real employee turnover. It is as an employee's own approximate likelihood that in the near future they will permanently leave the company. It was the action of an individual think to leave the organization ${ }^{(11)}$.Head nurse's turnover is extremely expensive and can have negative consequences, whether involuntarily such as separation imposed by the employer or voluntarily such as resignations. The potential negative effect of turnover on companies could be due to high hiring costs, preparation and 
recruitment of new employees, loss of income during recruitment selection and retention, low- performance or skillful workers, and deterioration of interpersonal and interaction systems ${ }^{(\mathbf{1 2})}$. 2- Significant of the study

The head nurses consider promotions and upward hierarchical movement as indicators of success at work but due to some factors for all organizations such as business reengineering, downsizing, flattening hierarchies, and unplanned career management in organization that lead to career plateaued. Career plateau is the point in a career that additional hierarchical promotion is very lower.

Head nurses who experience career plateau lose their morale when they continue to work in the same job over a long period of time. Head nurses may take actions to remove themselves from the situation, withdraw from organizational involvement, lower their productivity, lack of job satisfaction and job commitment, increase the level of turnover intention, and decrease level of creativity inertia all of this have negative effect of all organization. Career plateau accounts for a significant variance in three work outcomes namely, career satisfaction, job satisfaction, and turnover intentions. So, this study aim to investigate the effect of career plateau on head nurses career and job satisfaction and turnover intentions at Main Mansura University Hospital. Aim of the study

To investigate the effect of career plateau on head nurses' career and job satisfaction and turnover intentions at Main Mansoura University Hospital through:

1- Assess career plateau among head nurses at main Mansoura University Hospital.

2- Assess career satisfaction among head nurses at main Mansoura University Hospital.

3- Assess job satisfaction among head nurses at main Mansoura University Hospital.

4- Assess turnover intention among head nurses at main Mansoura University Hospital

5- Assess the effect of career plateau on head nurses career and job satisfaction and turnover intentions at Main Mansoura University Hospital

Research questions:-

Q1: What is the effect of career plateau on head nurses' career and job satisfaction and turnover intentions at Main Mansoura University Hospital?

\section{3- Method Research design:}

this study.

Descriptive design was used in

\section{The study setting}

This study was conducted at Main Mansoura University Hospital that provide a wide spectrum of health service at Delta Region. Mansoura University Hospital occupied with 1800 beds and includes 20 departments (surgical, medical, orthopedic, etc.....) in addition to many units attached to the main building.

Subjects of the study:

The study was include all head nurses who are available during the time of data collection at Main Mansoura University Hospital.

Tool of data collection

Tool (1): Career Plateau Questionnaire:

This tool was developed by Milliman (1992) ${ }^{(13)}$ and modified by Jolie (2014) ${ }^{(14)}$.

It consists of two parts as follows:

Part I: Demographic Information.

It covers items as gender, age, years of experience for the current 
hospital, position, and level of education.

\section{Part II: Career Plateau items.}

This part aims to assess career plateau. It consists of 12 items, their responses was measured by five-point Likert scale rang from $(1=$ strongly disagree to $5=$ strongly agree).

Tool (2): Career Satisfaction, Job Satisfaction and Turnover Intention Questionnaire:

This tool was developed by Kransz (1995) ${ }^{(\mathbf{1 5})}$ and modified by Jolie (2014) $)^{\circ}$ It consists of 28 items that cover three main parts as follows:

First Part aim to assess career satisfaction. It consists of 5 items, their responses was measured by five-point Likert scale rang from $(1=$ strongly disagree to $5=$ strongly agree),

Second Part aim to assess job satisfaction. It consists of 20 items, their responses was measured by five-point Likert scale rang from (1=very dissatisfied to $5=$ very satisfy).

Third Part aim to assess turnover intention. It consists of 3 items, their responses was measured by five-point Likert scale rang from (1=strongly disagree to $5=$ strongly agree).

(The sub-items with $60 \%$ agree or higher will be considered Career Plateau).

Validity and reliability:

Tool was modified and translated to Arabic language by the researcher. It was established for face and content validity by a panel of five expertise from faculties of nursing at Mansoura University who revised the tools for clarity, relevancy, applicability, comprehensiveness, understanding, and ease for implementation and according to their opinions modifications were applied. Reliability test of the study tools, career plateau on head nurses' career and job satisfaction, and turnover intention, were tested by Cronbach's Alpha reliability was computed and found (0.798), (0.814) respectively.

Pilot study:

A pilot study was conducted on $10 \%$ of total study subject to test the clarity and feasibility of items. And whether they were understandable, and to determine.

\section{Ethical consideration:-}

The Research Ethical Committee of the Faculty of Nursing, Mansoura University, received ethical approval. An official permission was obtained from the hospital's responsible administrator to perform the report. An informed consent was obtained from head nurses who accept to participate in the study after providing the explanation of nature and aim of the study. All participants have been notified that thestudy

is voluntary and at any time they are allowed to withdraw from the study. All participants were told that the data obtained was confidential and that the study sample was safeguarded.

\section{Statistical analyzing}

SPSS software (Statistical Software for Social Sciences, version 19, SPSS Inc. Chicago, IL, USA) was used in organized, tabulated and statistically analyzed the data collected. The range, mean and standard deviation have been calculated for quantitative data. For qualitative data, which defines a categorical set of data by frequency, proportion or percentage of each type, correlation between two groups and more was performed using a Chi-square test (square test). Student t-test was used to compare means of two groups of independent sample parametric results. The $F$ value of the ANOVA test was calculated to compare more than two means of parametric data. Using the 
correlation coefficient (r) of Pearson, correlation between variables was evaluated. Significance for interpreting the results of relevant experiments was adopted at $\mathrm{p}<0.05$ (Dawson \& and Trapp, 2001).

4- Results:

Table (1): Illustrated Personal characteristics of head nurses at main Mansoura university hospital. According to the table, total studied sample are 88 head nurses. This table showed that majority of nursing staff were female $(94.3 \%)$ while male represented $(5.7 \%)$ and $(51.1 \%)$ of studied sample were more than $35 y$ ears old, while a small percentage $(4.5 \%)$ of them were below the

aged 25 years old. In concerning years of experience, $(47.7 \%)$ of studied sample had professional experience more than 10 years, while $(5.7 \%)$ had $20-25$ years of experience. Regarding educational level most of them $(81.8 \%)$ had a bachelor's degree, While small percentage (18.2\%) Higher than bachelor degree.

Table (2): Illustrates the Presence of career plateau and its score of the studied head nurses at Main Mansoura University Hospital. According to the table, $58 \%$ of studied sample have career plateau which range from (41-60), while $42 \%$ of them don't have career plateau which ranged from (12-40). The mean score is $(41.18 \pm 3.65)$ which indicate have of career plateau as perceived by head nursing.

Table (3): Illustrated Mean scores and levels of Career satisfaction of the studied head nurses at Main Mansoura University Hospital. $64.8 \%$ of studied sample have low level of career satisfaction which range from (5-14), while $8.0 \%$ of them have high level of career satisfaction which ranged from (21-25).the mean score is $(13.60 \pm 4.39)$ which indicate low level of career satisfaction as perceived by head nursing.

Table (4): Illustrated Mean scores and levels of job satisfaction of the studied head nurses at Main Mansoura University Hospital. $62.5 \%$ of studied sample have low level of job satisfaction which range from (20-59), while $6.8 \%$ of them have high level of job satisfaction which ranged from (81-100). The mean score is $(56.64 \pm 12.16)$ which indicate low level of job satisfaction as perceived by head nursing.

Table (5): Illustrated Presence of turnover intention and its score of the studied head nurses at Main Mansoura University Hospital. $65.9 \%$ of studied sample have turnover intention which range from (10-15), while $34.1 \%$ of them don't have turnover intention which ranged from (3-9). The mean score is $(9.41 \pm 2.63)$ which indicate yes of turnover intention as perceived by head nursing.

Table (6): there is no significant relationship between presence of career plateau situation and level of career and job satisfaction and presence of turnover intension among the studied head nurses, but the percentage show that $(68.6 \%)$ of total career plateau have low of total career satisfaction in compered with $(59.5 \%)$ of haven't career plateau was low of total career satisfaction, while $(66.7 \%)$ of total career plateau have low of total job satisfaction in compered with $(56.8 \%)$ of haven't career plateau was low of total career satisfaction, and while $(29.4 \%)$ of total career plateau have low of Turnover intention in compered with $(40.5 \%)$ of haven't career plateau was low of total Turnover intention .

Figure (1): show the mean scores of career and job satisfaction and scores of turnover intention in relation to career plateau situation among the studied head nurses at Main Mansoura University Hospital $(\mathrm{n}=88)$. 
Asmaa Elwan Mohammed et. al.

Table (1): Demographic data of the studied head nurses at Main Mansoura University Hospital $(\mathrm{n}=88)$.

\begin{tabular}{|c|c|c|}
\hline \multirow[t]{2}{*}{ Variables } & \multicolumn{2}{|c|}{$\begin{array}{l}\text { The studied head nurses } \\
(\mathrm{n}=88)\end{array}$} \\
\hline & $\mathbf{N}$ & $\%$ \\
\hline $\begin{array}{l}\text { Sex: } \\
\quad \text { Male } \\
\text { Female }\end{array}$ & $\begin{array}{c}5 \\
83\end{array}$ & $\begin{array}{c}5.7 \\
94.3\end{array}$ \\
\hline $\begin{array}{c}\text { Age years: } \\
<25 \\
25-35 \\
>35\end{array}$ & $\begin{array}{c}4 \\
39 \\
45\end{array}$ & $\begin{array}{l}4.5 \\
44.3 \\
51.1\end{array}$ \\
\hline $\begin{array}{c}\text { Experience years: } \\
<10 \\
10-<20 \\
20-25\end{array}$ & $\begin{array}{c}42 \\
41 \\
5\end{array}$ & $\begin{array}{c}47.7 \\
46.6 \\
5.7\end{array}$ \\
\hline $\begin{array}{l}\text { Range } \\
\text { Mean } \pm \text { SD }\end{array}$ & & \\
\hline $\begin{array}{l}\text { Education level: } \\
\text { Completed bachelor degree } \\
\text { Higher than bachelor degree }\end{array}$ & $\begin{array}{l}72 \\
16\end{array}$ & $\begin{array}{l}81.8 \\
18.2\end{array}$ \\
\hline
\end{tabular}

Table (2): Presence of career plateau and its score among the studied head nurses at Main Mansoura University Hospital $(\mathrm{n}=88)$.

\begin{tabular}{|l|c|c|}
\hline \multirow{2}{*}{ Total career plateau situation } & \multicolumn{2}{|c|}{$\begin{array}{c}\text { The studied head nurses } \\
\text { (n=88) }\end{array}$} \\
\cline { 2 - 3 } & N & \% \\
Career plateau situation: & 37 & 42.0 \\
No (12-40) & 51 & 58.0 \\
Yes (41-60) & \multicolumn{2}{|c}{$30.00-51.00$} \\
Career plateau situation scores: $(12-60)$ & \multicolumn{2}{|c|}{$41.18 \pm 3.65$} \\
Range & \multicolumn{2}{|c|}{} \\
Mean \pm SD & \multicolumn{2}{|c|}{} \\
\hline
\end{tabular}

Table (3): Career satisfaction score and level among the studied head nurses at Main Mansoura University Hospital $(\mathrm{n}=88)$.

\begin{tabular}{|c|c|c|}
\hline \multirow[t]{2}{*}{ Total career satisfaction } & \multicolumn{2}{|c|}{$\begin{array}{l}\text { The studied head nurses } \\
(\mathrm{n}=88)\end{array}$} \\
\hline & $\mathbf{N}$ & $\%$ \\
\hline \multicolumn{3}{|l|}{ Total career satisfaction level: } \\
\hline$(<50 \%)$ & 57 & 64.8 \\
\hline Moderate & 24 & 27.3 \\
\hline High $\quad(>75 \%) \quad(21-25)$ & 7 & 8.0 \\
\hline \multicolumn{3}{|l|}{ Career satisfaction scores: $(5-25)$} \\
\hline Range & & \\
\hline Mean \pm SD & & \\
\hline
\end{tabular}


Table (4): Job satisfaction score and level among the studied head nurses at Main Mansoura University Hospital $(\mathrm{n}=88)$.

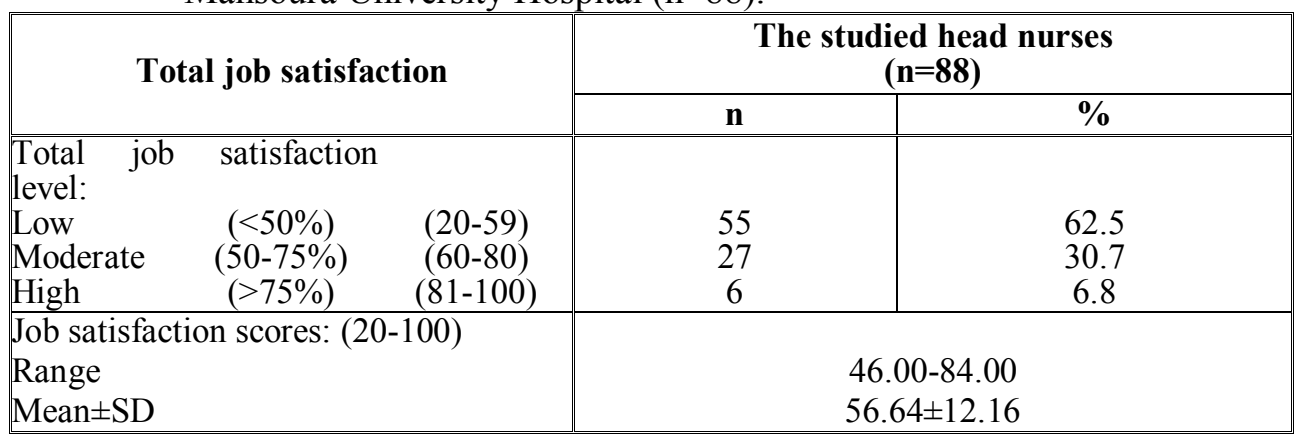

Table (5): Presence of turnover intention and its score among the studied head nurses at Main Mansoura University Hospital $(n=88)$.

\begin{tabular}{|c|c|c|}
\hline \multirow[t]{2}{*}{ Turnover intention } & \multicolumn{2}{|c|}{$\begin{array}{l}\text { The studied head nurses } \\
(\mathrm{n}=88)\end{array}$} \\
\hline & $\mathbf{N}$ & $\%$ \\
\hline $\begin{array}{l}\text { Turnover intention: } \\
\text { No }(3-9) \\
\text { Yes }(10-15) \\
\end{array}$ & $\begin{array}{l}30 \\
58\end{array}$ & $\begin{array}{l}34.1 \\
65.9\end{array}$ \\
\hline $\begin{array}{l}\text { Turnover intention scores: } \\
(3-15) \\
\quad \text { Range } \\
\text { Mean } \pm \text { SD }\end{array}$ & \multicolumn{2}{|c|}{$\begin{array}{l}3.00-14.00 \\
9.41 \pm 2.63\end{array}$} \\
\hline
\end{tabular}

Table (6): Relationship between presence of career plateau situation and level of career and job satisfaction and presence of turnover intension among the studied head nurses at Main Mansoura University Hospital $(n=88)$.

\begin{tabular}{|c|c|c|c|c|c|c|}
\hline \multirow{3}{*}{ Variables } & \multicolumn{4}{|c|}{$\begin{array}{c}\text { Total career plateau situation among } \\
\text { the studied head nurses } \\
(\mathbf{n}=\mathbf{8 8})\end{array}$} & \multirow{3}{*}{$\chi^{2}$} & \multirow{3}{*}{$\mathbf{P}$} \\
\hline & \multicolumn{2}{|c|}{$\begin{array}{c}\text { No } \\
(n=37)\end{array}$} & \multicolumn{2}{|c|}{$\begin{array}{c}\text { Yes } \\
(n=51)\end{array}$} & & \\
\hline & $\mathbf{n}$ & $\%$ & $\mathrm{n}$ & $\%$ & & \\
\hline \begin{tabular}{|l} 
Total career satisfaction level: \\
Low \\
Moderate \\
High \\
\end{tabular} & $\begin{array}{c}22 \\
11 \\
4 \\
\end{array}$ & $\begin{array}{l}59.5 \\
29.7 \\
10.8 \\
\end{array}$ & $\begin{array}{c}35 \\
13 \\
3 \\
\end{array}$ & $\begin{array}{c}68.6 \\
25.5 \\
5.9 \\
\end{array}$ & 1.274 & 0.584 \\
\hline $\begin{array}{l}\text { Total job satisfaction level: } \\
\text { Low } \\
\text { Moderate } \\
\text { High }\end{array}$ & $\begin{array}{c}21 \\
12 \\
4\end{array}$ & $\begin{array}{l}56.8 \\
32.4 \\
10.8\end{array}$ & $\begin{array}{c}34 \\
15 \\
2\end{array}$ & $\begin{array}{c}66.7 \\
29.4 \\
3.9\end{array}$ & 1.893 & 0.388 \\
\hline $\begin{array}{l}\text { Turnover intention: } \\
\text { No }(3-9) \\
\text { Yes }(10-15) \\
\end{array}$ & $\begin{array}{l}15 \\
22 \\
\end{array}$ & $\begin{array}{l}40.5 \\
59.5 \\
\end{array}$ & $\begin{array}{l}15 \\
36 \\
\end{array}$ & $\begin{array}{l}29.4 \\
70.6 \\
\end{array}$ & 1.182 & 0.277 \\
\hline
\end{tabular}




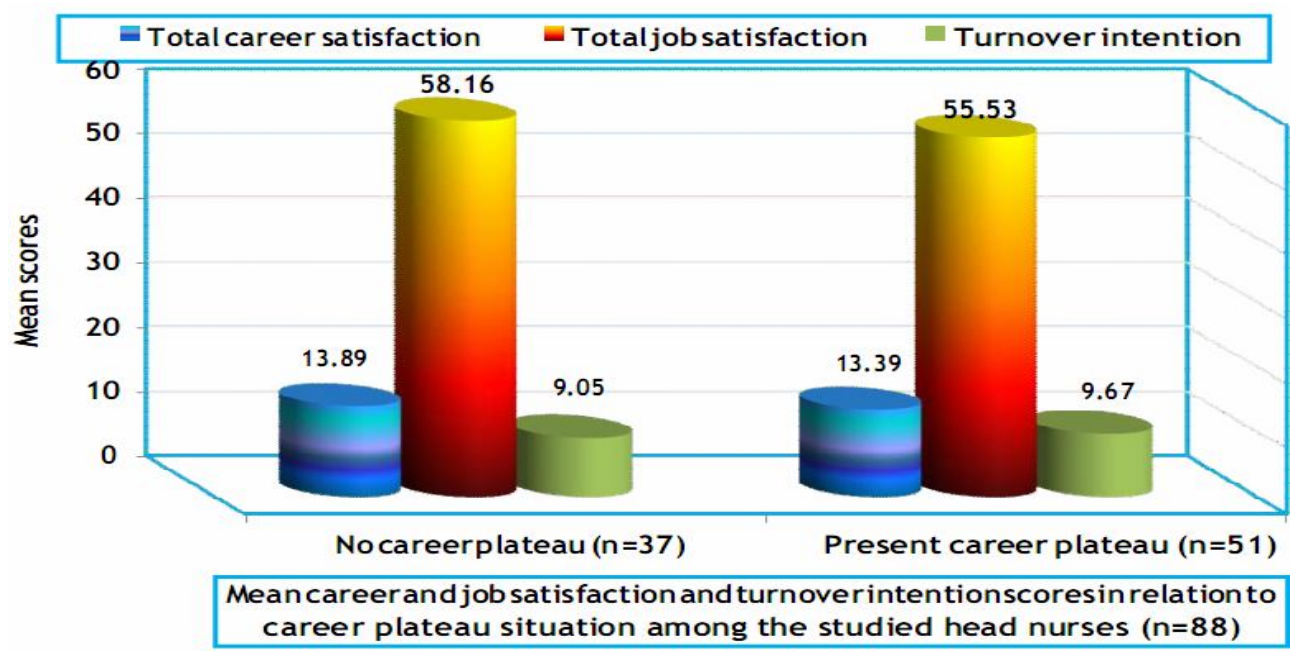

Figure (1): Mean scores of career and job satisfaction and scores of turnover intention in relation to career plateau situation among the studied head nurses at Main Mansoura University Hospital $(\mathrm{n}=88)$.

\section{5- Discussion:}

The changes in the health environment, such as the restructuring and downsizing trend, have resulted in greater numbers of people competing for fewer promotional opportunities. Many head nurses are experiencing longer assignments in the same position with fewer prospects for future vertical mobility. Today's context, many head nurses are expose to have a career plateau and stay in the same place for longer, restricting their career path and reducing the possibility of potential advancement opportunities, resulting in different degrees of effect on career satisfaction, job satisfaction and turnover. (Hossain, 2018) ${ }^{(16)}$.

The present study aims to determine the effect of career plateau on head nurses' career and job satisfaction and turnover intentions through assessing head nursing career plateau, career and job satisfaction and turnover intentions and detecting relation between career plateau, career and job satisfaction and turnover intentions.

The study results revealed that the mean score of career plateau is high ( high level of occurrence ) it may be due to head nurses feeling restricted in role or no longer feeling challenged or engaged by work. So that, majority of head nursing have the following behaviors as decrease commitment to work and hospital performance, and increase stress, turnover, and absence.

On the same line with result Gaturu, (2018) (16) Find that career plateaued workers have become dissatisfied and are not inspired to continue working harder because the efforts they put into their work in the company have not been appreciated and as such their work may not be of value to them, leading to disappointment, disinterest, discontent with their job and an intention to quit.

Furthermore, result Yang, (2016)

(17) founded that employees who perceive 
a low likelihood of future promotions, lack of job challenge report as signs of failure, limited opportunities available in the current unpredictable working environment or have chosen to be in the state of plateau are lower job satisfaction, lower organizational commitment and higher turnover intention and have intention to leave. As well, Su, Kuo, Cheung, Hung, Lu, \& Cheng, (2017) (18) assumed that the greater perception of career plateauing is due to rapid technological development, social tendencies, and organizations have engaged in restructuring, and downsizing is an unavoidable.

The study results revealed that the mean score of total career satisfaction is low (low level of occurrence) it may be due to the head nurses constantly feeling challenged in their Job. So that, majority of head nurses never progress toward meeting their overall career goals, goals for income and goals for Advancement. On the other hand, low level of career satisfaction is associated with "unskilled or inappropriately trained staff, laborious tasks such as documentation, repetition of duties, tensions within role expectations, role ambiguity, role conflict, and feeling overloaded"

On the same line with result Joo, \& Ready, (2012) ${ }^{(19)}$ Who report that career satisfaction was weak because employees do not seek better career opportunities in other organizations so that employees are more satisfied with their higher performance goals. Since performance-oriented individuals either strive to illustrate their capacity through job performance or to avoid the negative judgments of their ability. These result in contrast with Trivellas, Kakkos, Blanas, \& Santouridis, (2015) ${ }^{(20)}$ It was found that workers with a high level of scientific skills have demonstrated an enhanced level of career satisfaction that may reflect the assessment of the employee's condition of employment with respect to, among other things, their salaries, fringe benefits, accomplishment, independence, appreciation, interaction, working conditions, significance of work, employees, level of professionalism, internal climate, Personal and social interactions, monitoring, meaningful affectivity, job stability, flexibility in the workplace and team building.

The study results revealed that the mean score of total job satisfaction is low (low level of occurrence) it may be due to the head nurses constantly feeling the time pressure, lack of resources and heavy workloads. So that, majority of head nurses were busy all the time and don't have chance to work alone on the job to advancement and don't have the chance become somebody in the Community.

On the same line with result Jalagat, Dalluay, Al-Zadjali, \& AlAbdullah, (2017) ${ }^{(21)}$ was found that the negative impact on job satisfaction is due to managerial relationships, diversity of work, acknowledgement rates, relationships with staff, job security and task rotation .These result in contrast with Jessen, (2010) (22) Find that employees were highly satisfied with their jobs may be due to social desirability, which often affects how people respond, since the requirements for the current jobs of employees are determined by the contract of employment, most employees express general satisfaction even if they wish to have a different kind of work.

The study results revealed that the mean score of turnover intention is high ( high level of occurrence ) it may be due to head nurses feeling higher level of job 
stress and decrees promotion opportunities, pay level and rewards. So that there are more likely to feel angry, vengeful, dissatisfied and have the intention of leaving the hospital for another.

On the same line with result, Belete, (2018) ${ }^{(\mathbf{2 3 )}}$ Report that head nurses extremely intentional turnover along with wages and service conditions, performance at work, career development, work environment, job satisfaction, administrative style, worker engagement and perceived professional opportunities outside the organization and lack of career development opportunities within the organization. These result in contrast with Puni, Agyemang, \& Asamoah, (2016) ${ }^{(24)}$ found that head nurses were a lower turnover intention because they have regularly clearly defined roles and feedback on their results and their input is also included in the decision-making process. Punishments as a form of reprimand are the last choice, acknowledging and rewarding high performance.

Correlation between career plateau and career satisfaction. The study results revealed that there was no significant relation between career plateau and career satisfaction but the percentage show that high career plateau level have low total career satisfaction. This result due to large number of head nurses don't satisfied with the progress that have made towards meeting your overall career and goals for the development of new skills are reached to point where do not expect to move much higher in your hospital and get ahead in your hospital was limited .

On the same line with the result Drucker-Godard, Fouque, Gollety, \& Le Flanchec, (2015) ${ }^{(25)}$ who have reported that plateaued workers are more unhappy with their work than others because of job stagnation, development does not happen, and emotions of being leaving over are frequent.. Furthermore, Su, Kuo, Cheung, Hung, Lu, \& Cheng, $\mathbf{( 2 0 1 7}^{(\mathbf{2 6})}$ verified that the greater perception of career plateauing ware less career satisfaction due to rapid technological development and social tendencies that have engaged in restructuring, and downsizing that lead to shortage of learning and challenging opportunities and the overall staleness of the job itself have increase the difficulty in the vertical movement within organization or in switching to another profession outside the organization.

Correlation between career plateau and job satisfaction. The study results revealed that there was no significant relation between career plateau and job satisfaction but the percentage show that high career plateau level have low total job satisfaction. This result due to large number of head nurses don't have the chance to do something that makes use of abilities and tell people what to do which effect of an opportunity to learn and grow a lot in your current job so that don't expect to obtain a higher level in your hospital in the near future. The salary paid by the company was not tied up with the level of recognition, job security, and the competence of your supervisor in making decision.

On the same line with the result, Drucker-Godard, Fouque, Gollety, \& Le Flanchec, (2015) ${ }^{(27)}$ Results show that job satisfaction was negatively associated with the career plateau. Career-plateaued workers have become dissatisfied and are not inspired to keep working harder. They might have concluded that there was no incentive for the efforts they put into their work in the 
company, and as such their work may not be important to them, which contributes to job dissatisfaction.

Correlation between career plateau and turnover intention. The study results revealed that there was no significant relation between career plateau and turnover intention but the percentage show that high career plateau level have high total turnover intention. This result due to large number of head nurses don't have the chance to do talent, skill, experience in current position is for progress. These conditions lead to stress, frustration, and dissatisfaction among employees is causes to leave the hospital and looking for another hospital to work and improve your skills. On the same line with the result Godshalk, \& Fender, (2015) ${ }^{\text {(28) }}$ who It has been reported that employees on the plateau have less than performance or perceive few job referral opportunities. In these situations, employees make choices about leaving the company and use training, coaching, mentoring, and career planning as tools to pursue professional development in another organization with preparation for new career opportunities.

\section{6- Conclusion:-}

Based on the study findings, there was no significant correlation between career plateau and career, job satisfaction and turnover intention among head nurses at Main Mansoura University Hospital. It can be concluded that when the mean score of total career plateau was highest, the mean score of total career and job satisfaction was lowest. But when the mean score of total career plateau was highest the mean score of total turnover intention was highest.

\section{7- Recommendation:-}

Based on the findings of this study, the following recommendations are suggested:
- Should develop a clear road map for advancing the career of head nurses to reduce the plateauing of careers.

- The working conditions of the head nurses should improve by supplying all the tools necessary for their work and by using job enrichment to make working conditions more interesting.

- Should identify and control the factors (working relationships, increase work motivation, quality of life, and salary levels) that create positive attitudes towards increasing productivity of head nurses, encouraging creative, collaborative management and recruitment

- Create a mentoring program in which older and more experienced head nurses serve as models and mentors for young and new head nurses in the profession to encourage and inspire them to stay in the profession

- Create ways to increase the satisfaction of current jobs. This can be done by establishing job competition and personal incentives.

- Should talk to the head nurses in the job roles you want and ask for advice on how to proceed to their stage.

\section{References}

[1]. Zehir, C., Üzmez, A., \& Yıldız, H. (2016). The effect of SHRM practices on innovation performance: The mediating role of global capabilities. Procedia- Social and Behavioral Sciences, 235, 797-806.

[2]. Alivand, H., \& Ebrahimpour, H. (2015). Effects of Career Plateau to the desire for professional development of staff. 
[3]. Farooq, N. (2017). An Empirical Study of Career Plateau, Organizational Commitment and Job Performance; A Case of Private Sector Universities in Peshawar City. City University Research Journal, 7(2). [4]. Goldin, C. (2014). A grand gender convergence: Its last chapter. American Economic Review, 104(4), 1091- 1119.

[5]. Farooq, N., \& Tufail, M. (2017). An Empirical Study of Career Plateau, Organizational Commitment and Job Performance; A Case of Private Sector Universities in Peshawar City. HEC RECOGNIZED

[6].Azodi, V., Mohammadipour, M. A., Dehghani, M., Hamedani, A., \& Shafiee, H. (2016). Studying the relationship between lack of job promotion and career plateau of staff: A case study in wellbeing office of Kerman. International Journal of Management, Accounting \& Economics, 3(1), 75-84.

[7].Joo, B. K., \& Ready, K. J. (2012). Career satisfaction: The influences of proactive personality, performance goal orientation, organizational learning culture, and leader-member exchange quality. Career Development International, 17(3), 276-295. [8].Trivellas, P., Kakkos, N., Blanas, N., \& Santouridis, I. (2015). The impact of career satisfaction on job performance in accounting firms. The mediating effect of general competencies. Procedia Economics and Finance, 33, 468-476.

[9].Jessen, J. T. (2015). Job satisfaction and social rewards in the social services. Journal of Comparative Social Work, 5(1).

[10]. Jessen, J. T. (2015). Job satisfaction and social rewards in the social services. Journal of

Comparative Social Work, 5(1).

[11]. Ahmed, M., \& Hidayat, I. (2015). Determinants of employee's turnover intention: A case study of the Islamia University of Bahawalpur. African Journal of Business Management, 9(17), 615-623.

[12]. Arshad, H., \& Puteh, F. (2015). Determinants of Turnover Intention among Employees. Journal of Administrative Science, 12 (2).

[13]. Milliman, J. (1992). "Cause, consequences and moderating factors of career plateauing" Doctoral dissertation, University of Southern California.

[14]. Trang, T.T.H\& Chang, H \&Wu, T. (2014). The Study of Relationship between Career Plateau, Job Satisfaction and Turnover Intention. Evidence from Vietnamese Companies." PhD disster.

[15]. Kransz, M., (1995). "Predictors of intentions to leave the ward, the hospital, and the nursing profession: a longitudinal study", Journalof Organisational Behaviour, Vol.16, No.3, pp.277-288.

[16]. Hossain, T, (2018). Effects of Perceived Career Plateau on Work Related Attitudes: A Study on Employees of Bangladeshi Private Organizations.

Journal of Applied Chemistry, I, 44-54

[17]. Yang, W. N. (2016). 'That's Not what I Signed Up for!'A Longitudinal Investigation of the Impact of Unmet Expectation in the Relation between Career Plateau and Job Outcomes(Doctoral dissertation, The University of Manchester (United Kingdom)).

[18]. Su, T. W., Kuo, J. H., Cheung, Y. H., Hung, C. Z., Lu, S. H., \& Cheng, J. W. (2017). Effect of 
Structural/Content Career Plateaus on Job Involvement: Do Institutional/Occupational Intentions Matter?.

[19]. Joo, B. K., \& Ready, K. J. (2012). Career satisfaction: The influences of proactive personality, performance goal orientation, organizational learning culture, and leader-member exchange quality. Career Development International, 17(3), 276-295.

[20]. Trivellas, P., Kakkos, N., Blanas, N., \& Santouridis, I. (2015). The impact of career satisfaction on job performance in accounting firms. The mediating effect of general competencies. Procedia Economics and Finance, 33, 468-476.

[21]. Jalagat, R., Dalluay, V., AlZadjali, A. K., \& Al- Abdullah, A. (2017). The Impacts of Job Satisfaction on Employee Turnover: A Case Study of Oman Air in Sultanate Of Oman. European Academic Research, 5, 331-374.

[22]. Jessen, J. T. (2010). Job satisfaction and social rewards in the social services. Journal of comparative social work, 2010(1).

[23]. Belete, A, K. (2018). Turnover Intention Influencing Factors of Employees: An Empirical Work Review. Journal of Entrepreneurship \&Organization Management, (10) 2169-026X
[24]. Puni, A., Agyemang, C. B., \& Asamoah, E. S. (2016). Leadership styles, employee turnover intentions and counterproductive work behaviours. International Journal of innovative research and development, 5(1), 1- 7.

[25]. Drucker-Godard, C., Fouque, T., Gollety, M., \& Le Flanchec, A. (2015). Career plateauing, job satisfaction and commitment of scholars in French universities. Public Organization Review, 15(3), 335-351.

[26]. Su, T. W., Kuo, J. H., Cheung, Y. H., Hung, $C$.

Z., Lu, S. H., \& Cheng, J. W. (2017). Effect of Structural/Content Career Plateaus on Job Involvement: Do Institutional/Occupational Intentions Matter?.

[27]. Drucker-Godard, C., Fouque, T., Gollety, M., \& Le Flanchec, A. (2015). Career plateauing, job satisfaction and commitment of scholars in French universities. Public Organization Review, 15(3), 335-351.

[28]. Godshalk, V. M., \& Fender, C. M. (2015). External and internal reasons for career plateauing: Relationships with work outcomes. Group \& Organization Management, 40(4), 529-559. 